\title{
FAKTOR PENYEBAB ANAK PUTUS SEKOLAH DI NAGARI LADANG PANJANG KECAMATAN TIGO NAGARI KABUPATEN PASAMAN
}

\author{
Ika Laksita Warti ${ }^{1}$, Yurni Suasti ${ }^{2}$, Nofrion ${ }^{2}$ \\ Program Studi Pendidikan Geografi \\ FIS Universitas Negeri Padang \\ Email: ikalaksitawarti123@gmail.com
}

\begin{abstract}
ABSTRAK
Penelitian ini bertujuan untuk mendeskripsikan faktor penyebab anak putus sekolah di Nagari Ladang Panjang, Kecamatan Tigo Nagari, Kabupaten Pasaman. Jenis penelitian ini adalah kualitatif. Subjek pada penelitian ini adalah anak yang putus sekolah dan orang tuanya. Untuk menentukan informan menggunakan teknik purposive sampling. Hasil penelitian menemukan bahwa faktor penyebab anak putus sekolah di nagari Ladang Panjang adalah : 1) kurang minat sekolah yaitu prestasi belajar anak rendah, anak merasa pelajaran yang diberikan terkesan sulit dan tidak memahami pelajaran dengan adanya rasa malas sehingga tinggal kelas. 2) faktor ekonomi keluarga, pendapatan orang tua yang rendah berkisar antara Rp 400.000 - Rp 1.500.000 dengan jumlah tanggungannya 3 sampai 5 orang. 3) pergaulan dengan teman yang tidak bersekolah, dan adanya pergaulan bebas yang membuat anak memilih menikah dari pada bersekolah. Hal ini yang menyebakan banyak anak-anak yang kurang minat bersekolah dan lebih memilih putus sekolah.
\end{abstract}

Kata kunci : Faktor Penyebab, Anak Putus Sekolah

\section{ABSTRACT}

This study aims to describe the factors that cause school dropouts in Nagari Ladang Panjang, Tigo Nagari District, Pasaman Regency. This type of research is qualitative. The subjects in this study were children who dropped out of school and their parents. To determine informants using purposive sampling techniques. The results of the study found that the factors causing school dropouts in Ladang Panjang village were: 1) lack of school interest, namely low learning achievement of children, children felt the lessons given seemed difficult and did not understand the lesson with the feeling of being lazy so staying class. 2) family economic factors, low parental income ranging from $R p$ 400,000 - Rp 1,500,000 with a number of dependents 3 to 5 people. 3) association with friends who are not in school, and the existence of promiscuity that makes children choose to marry rather than going to school. This has caused many children who are less interested in going to school and prefer to drop out of school.

Keywords : Causative Factor, School Dropouts

\footnotetext{
${ }^{1}$ Mahasiswa Program Studi Pendidikan Geografi

${ }^{2}$ Dosen Jurusan Geografi Fakultas Ilmu Sosial Universitas Negeri Padang
} 


\section{PENDAHULUAN}

Pendidikan merupakan hal yang sangat penting dalam kehidupan manusia. Surtani (2017) mengatakan pendidikan nasional berfungsi mengembangkan kemampuan dan membentuk watak serta peradaban bangsa yang bermartabat dalam rangka mencerdaskan kehidupan bangsa. Dengan pendidikan, manusia bisa menempati kedudukan yang lebih tinggi dan lebih dihormati serta disegani oleh manusia yang lain. Tanpa pendidikan suatu kelompok manusia dapat hidup berkembang sejalan dengan aspirasi (cita-cita) untuk maju dan sejahtera.

Pendidikan juga merupakan tiang bagi suatu negara dalam tindakan untuk pembangunan suatu bangsa. Hal tersebut sesuai dengan Undang-Undang Sistem Pendidikan Nasional No. 20 Tahun 2003 pada Bab VI Pasal 13 Tentang Jalur dan Jenis Pendidikan, pada ayat (1) dinyatakan bahwa proses pelaksanaan pendidikan di Indonesia dilaksanakan melalui tiga jalur, yaitu jalur pendidikan formal, jalur pendidikan non formal dan jalur pendidikan informal. Jalur pendidikan formal memiliki jenjang pendidikan dari pendidikan dasar, pemdidikan menengah, dan pendidikan tinggi serta memiliki jenis pendidikan umum, kejuruan, akademik profesi, vokasi, keagamaan dan khusus.

Indonesia, pendidikan diwajibkan bagi seluruh warga adalah pendidikan dua belas tahun. Program wajib belajar dua belas tahun merupakan suatu program yang menegaskan anak-anak khususnya anak-anak Indonesia harus sekolah minimal sampai dua belas tahun.

Sejalan dengan kebijakan pemerintah yang berhubungan dengan pendidikan dalam rangka mewujudkan gerakan wajib belajar 12 tahun masih terdapat banyak kendala dalam implementasi di lapangan. Salah satunya masih banyak anak yang belum dapat menikmati adanya pendidikan dan masih banyak terdapat anak yang putus sekolah.

Provinsi Sumatera Barat, angka putus sekolah dari Tahun 2013 sampai Tahun 2015 selalu mengalami peningkatan. Dilihat pada jenjang pendidikan Sekolah Dasar jumlah anak yang putus sekolah berkisar $0.21 \%$ sampai $0.22 \%$ dan untuk jenjang pendidikan Sekolah Menengah

Pertama $\quad 0.37 \%$ sampai $0.46 \%$. sedangkan untuk jenjang pendidikan Sekolah Menengah Atas dan Madrasah Aliyah dan Sekolah Menengah Kejujuran jumlah anak yang putus sekolah berkisar $0.89 \%$ sampai $0.95 \%$ ( Bappeda Sumbar, 2016).

Angka putus sekolah merupakan hal yang sangat serius di Indonesia. Angka putus sekolah disebabkan oleh berbagai faktor yaitu minat sekolah, motivasi berprestasi, kondisi ekonomi, tingkat pendidikan orang tua dan faktor lingkungan. Minat menurut Slameto (2003) adalah suatu rasa suka dan rasa keterkaitan pada suatu hal tanpa ada paksaan. Minat anak sangat dipengaruhi oleh rangsangan baik berasal dalam diri anak itu sendiri yang berupa bakat, kemampuan dan psikis maupun yang berasal dari luar diri yang 
berupa keadaan ekonomi, lingkungan dan kesempatan. Motivasi berprestasi menurut McCleland dalam Sobur, (2003) merupakan konsep personal yang merupakan faktor pendorong untuk meraih atau mencapai sesuatu yang diinginkan agar meraih kesuksesan.

Faktor kondisi ekonomi, Suyanto (2010) mengatakan faktor yang datang dari pendapatan tiap keluarga. Jika rendah pendapatan suatu keluarga dimungkinkan akan berpengaruh pada pemenuhan kebutuhan baik itu pendidikan. Tingkat pendidikan orang tua, Ajiz (2012) dalam penelitiannya tinggi rendahnya pendidikan orang tua dapat mempengaruhi anak melanjutkan pendidikan. Faktor lingkungan baik itu keluarga, sekolah, dan tempat tinggal akan memberikan pengaruh besar terhadap anak seperti yang diungkapkan Suyanto (2010) yaitu jika anak setiap hari anak bergaul dan bermain dengan teman yang tidak sekolah maka secara teoritis memiliki pangaruh sangat kuat lama kelamaan akan ikut untuk tidak bersekolah atau memutuskan untuk berhenti sekolah.

Hal tersebut juga terjadi di Kecamatan Tigo Nagari, Kabupaten Pasaman yang terdapat banyak anak putus sekolah terutama di Nagari Ladang Panjang. Dimana jumlah anak putus sekolah periode 2015 sampai 2017 adalah 103 orang. Jumlah anak putus sekolah tingkat Sekolah Dasar berjumlah 30 orang, tingkat Sekolah Menengah Pertama sejumlah 57 orang dan tingkat Sekolah Menengah Atas terdapat sebanyak 16 orang.

\section{METODE PENELITIAN}

Jenis penelitian ini adalah penelitian deskriptif kualitatif. Subjek penelitian ini adalah seluruh anak putus sekolah yang berada di Nagari Ladang Panjang, Kecamatan Tigo Nagari, Kabupaten Pasaman. Teknik pengambilan sample menggunakan teknik purposive sampling. Peneliti memiliki kriteria informan yang peneliti akan wawancarai adalah sebagai berikut :

1) Anak yang putus sekolah tingkat SD, SMP, dan SMA di Nagari Ladang Panjang.

2) Orang tua dari anak yang putus sekolah.

\section{HASIL PENELITIAN DAN PEMBAHASAN \\ Deskripsi Data}

Berdasarkan hasil penelitian di lapangan, maka hasil penelitian tentang faktor penyebab anak putus sekolah di Nagari Ladang Panjang akan dibahas dalam uraian berikut ini:

\section{Tingkat Sekolah Dasar}

Wawancara dengan Fiki (13

Tahun) alasan dia berhenti sekolah karena dia malas sekolah, keinginan untuk pergi sekolah itu tidak ada dan berat rasanya untuk pagi-pagi ke sekolah. Hal ini di perkuat wawancara dengan orang tua Fiki yang memaparkan bahwa anak saya putus sekolah karena dia tidak ingin saja untuk sekolah dengan banyak alasan yang dia sampaikan kepada saya,saya lihat anak saya ini minatnya untuk sekolah itu tidak ada. Segala cara untuk membujuknya supaya bersekolah namun tetap tidak mau sekolah.

Wawancara dengan Roki (12 Tahun) alasan dia putus sekolah karena malas, dia lebih suka bermain dirumah dari pada bersekolah. Hal ini 
juga dibenarkan oleh orang tua Roki bahwa anaknya tidak ada minat unuk sekolah karena anaknya lebih memilih bermain dirumah dari pada di sekolah, selalu disuruh untuk sekolah dia tetap tidak mau sekolah.

Wawancara dengan Sandri (11 Tahun) alasan dia putus sekolah karena sakit yang tidak ada sembuhnya. Hal ini dikuatkan oleh orang tua sandri yaitu anak ibu sering sakit, ketika belajar tiba-tiba sakitnya kambuh, soalnya anak ibu tidak bisa terlalu berfikir. Dia sudah memiliki sakit ini sudah lama. Asal sudah mulai belajar sakit itu kambuh, maka dari itu ibu memutuskan dia tidak sekolah.

Wawancara dengan Chardo (12 Tahun) alasan putus sekolah karena malas saja untuk sekolah. Sekolah pun saya suka bermain-main dari pada belajar. Saya lebih suka dirumah bisa bermain dibandingkan sekolah. Hal ini juga diperkuat oleh orang tua Chardo mengatakan bahwa anak ibu kurang minatnya untuk sekolah dan malas untuk pergi sekolah, dengan banyak cara dilakukan seperti dinasehati, dikasih belanja lebih supaya dia mau pergi sekolah rela dia tidak dapat uang belanja asal dirumah.

Wawancara dengan Yogi (10 Tahun) alasan saya putus sekolah karena biaya tidak ada, ayah saya sudah meninggal sehingga saya harus bekerja sebagai tukang cuci motor. Adik saya 6 orang dan ibu saya sakitsakitan sehingga harus saya yang mencari uang untuk kebutuhan seharihari. Makanya saya berhenti sekolah hal ini dibenarkan oleh orang tua Yogi bahwa anaknya harus berhenti sekolah karena tidak ada biaya dan dia jadi tulang punggung keluarga karena saya sakit sakitan dan tidak bisa bekerja .

Wawancara dengan Rafi (13 Tahun) alasan anak putus sekolah karena biaya yang tidak ada. Dan saya juga sering tidak pergi sekolah karena saya lebih suka bermain dirumah dengan teman yang tidak sekolah. Hal ini disampaikan juga orang tua Rafi bahwa anaknya putus sekolah karena biaya tidak ada untuk kebutuhan sehari-hari saja susah tambah minat anaknya kurang anak dirumah sering bermain. Anak saya berjumlah 9 orang. yang bersekolah cuma satu orang kakaknya Rafi sampai SMA.

Tingkat Sekolah Menengah Pertama

Wawancara dengan Irfan (16 Tahun) alasan putus sekolah karena orang tua anak tidak ada biaya dan anak terpaksa di haruskan bekerja sebagai tukang panen sawit kadang sebagai buruh bangunan. Malahan orang tua anak jika ingin sekolah carilah uang sendiri. Hal ini dibenarkan oleh orang tua Irfan bahwa anak ibu putus sekolah karena tidak ada biaya untuk sekolah makan sehariharipun susah. Tambah ayah dia sudah meninggal. Ibu cuma kadang jual pinang untuk makan itupun tidak tiap hari makanya anak ibu bekerja untuk membantu ibu.

Wawancara dengan Meli (16 Tahun) alasan dia putus sekolah karena tidak ada biaya karena orang tua Meli sering sakit-sakitan dan tidak bisa 
bekerja dan ibunya sudah meninggal dunia sehingga dia memutuskan untuk berhenti sekolah. Hal ini dibenarkan oleh orang tua Meli, anak terpaksa untuk putus sekolah karena keadaan yang tidak memungkinkan anak untuk sekolah.

Wawancara dengan Alfajril (16 tahun) alasan putus sekolah karena malas sekolah, disekolah sering cabut dan bermain di kebun sawit dekat sekolah untuk merokok dan dirumah sering berteman dengan yang tidak sekolah sehingga dia tinggal kelas dan akhirnya malu untuk melanjutkan sekolah. Hal ini juga diperkuat oleh orang tua Alfajril bahwa anaknya tidak minat untuk sekolah dan tambah dia berhenti karena tinggal kelas dan malu untuk melanjutkan sekolah karena sama dengan adiknya. Susah payah untuk membujuknya supaya bersekolah tapi tetap tidak mau.

Wawancara dengan Beti (15 Tahun) alasan dia putus sekolah karena dia ingin menikah dan pasangan nya dekat dari rumah anak putus sekolah tersebut. Dan hal ini dibenarkan oleh orang tua Beti bahwa anak nya putus sekolah karena ingin menikah padahal segala keperluan sekolah di cukupkan supaya dia tidak berhenti sekolah akan tetapi dia keras untuk menikah.

Wawancara dengan Nia (15 Tahun) alasan putus sekolah karena sering berteman dengan anak yang tidak sekolah dan ikut pergi dengan teman-teman yang berpacaran dengan orang yang tidak sekolah sehingga juga ikut ikutan untuk berpacaran sehingga memutuskan menikah dan berhenti untuk sekolah. Hal ini dikuatkan oleh orang tua bahwa anaknya terpengaruh lingkungan. Orang tua mengira disekolah ternyata anaknya pergi dengan laki-laki dan akhirnya anak meminta untuk menikah.

Wawancara dengan Ikbal (14 Tahun) alasan putus sekolah karena ikut-ikutan teman yang lebih besar dan sering berteman dengan anak yang tidak sekolah dan ketika disekolah sering cabut dan bermain dikantin sekolah. dan pulang sekolah pun langsung bermain handphone dan akhrinya tinggal kelas. Sehingga malu untuk melanjutkan sekolah. Hal ini dibenarkan oleh orang tua Ikbal bahwa alasan putus sekolah karena tinggal kelas sehingga malu untuk melanjutkan sekolah lagi dan memutuskan untuk berhneti dan main-main saja dirumah lagi.

Wawancara dengan Yoga (14 Tahun) alasan putus sekolah karena sering ikut-ikutan teman yang tidak sekolah balapan motor. Sering ikutikutan balapan motor keluar daerah sehingga sering tidak masuk kelas dan merasa malas untuk sekolah karena sudah asyik bermain dengan teman yang tidak sekolah. Hal ini juga dibenarkan oleh orang tua bahwa anak tidak ingin sekolah dan anak meminta berhenti sekolah. susah payah untuk meminta dia tidak ikut-ikutan teman tidak sekolah tapi anak tetap mau berhenti sekolah.

Berdasarkan wawancara diatas di Nagari Ladang Panjang penyebab 
anak putus sekolah di tingkat Sekolah Menengah Pertama yaitu didominasi oleh faktor lingkungan. Salah satunya faktor pergaulan dengan teman- teman yang tidak sekolah dengan ikut-ikutan dan pengaruh teman sebaya dengan sering bermain- main dan berteman dengan lawan jenis sehingga anak putus sekolah di Nagari Ladang Panjang mamutuskan untuk menikah di usia muda dan sebagian anak putus sekolah karena faktor ekonomi keluarga yang pas - pasan sehingga anak harus bekerja menggantikan orang tua dan membuat anak memilih untuk berhenti sekolah.

\section{Tingkat Sekolah Menengah Atas}

Wawancara dengan Jefri (17 Tahun) alasan anak putus sekolah karena tidak minat untuk sekolah dan malas saja untuk pergi sekolah. kalau pergi sekolah sering lambat lambat supaya terlambat dan tidak sekolah. hal ini dibenarkan oleh orang tua alasan anak ibu tidak sekolah kerana minat nya kurang, disuruh pun sama kita tetap dia tidak mau. Sedih rasanya melihat dia tidak mau pergi sekolah. Sudah ditanya kenapa tidak pergi sekolah nak? Sekolah itu penting untuk masa depan nantinya dengan sekolah kita mudah dapat kerja. Tapi tetap dia tidak mau dengar, mau gimana lagi. Semenjak tidak sekolah sekarang dia bekerja ke kebun. kalau dorongan, motivasi segalanya sudah diberikan supaya dia sekolah tapi apa boleh buat dia tidak mau sekolah, dipaksa juga dia terus nanti malah kita yang susah.
Wawancara dengan Ridho (18 Tahun) alasan putus sekolah karena Alasan saya tidak sakolah lagi karena malas untuk sekolah. Di sekolah sering tidak masuk, cabut dan sering main diluar ketika jam pelajaran yang dilakukan merokok belakang sekolah sama teman - teman yang lain.. Kalau dirumah sering kena marah sama orang tua karena sering cabut sekolah dari pada seperti itu bagus tidak lagi. Sekarang kerja cuma putar- putar dan kerja buruh panen sawit. Hal ini dibenarkan oleh orang tua Ridho Alasan dia tidak sekolah karena kurangnya minat sekolah. Sering guru bilang kalau dia sering tidak masuk sekolah, sering juga di tegur tapi dia acuh dan tidak mau mendengarkan apa kata orang tua, kalau untuk perlengkapan sekolah cukup seperti uang belnja buku disediakan semuanya tapi anak tidak mau sekolah memilih berhenti.

Wawancara dengan Tesa (18 Tahun), alasan putus sekolah karena malas kalau biaya mencukupi. malas aja untuk pergi sekolah dengan kalau berteman banyak berteman dengan anak yang tidak sekolah, selama putus sekolah pekerjaan saya membantu orang tua dan sekarang saya sudah menikah. Hal ini juga disampaikan oleh orang tua Tesa alasan anak ibu putus sekolah karena minatnya tidak ada untuk sekolah. Untuk pergi sekolah malas. Susah menyuruhnya untuk sekolah tapi tetap juga tidak mau sekolah. Marah pun ibu dia tidak peduli. Kalau perlengkapan sekolah 
ada semua tercukupi tapi kemauan nya untuk sekolah tidak ada Tetap hatinya tak mau sekolah. Semenjak putus sekolah sekarang dia sudah menikah. Keputusan ini sebenarnya ibu tidak setuju tapi mau bagaimana ini kemauan nya. Tidak mungkin ibu paksa.

Wawancara dengan Mela (17 Tahun), alasan saya karena sekolah sering pindah- pindah gara- gara pindah rumah. Tinggal kelas gara- gara itu sering main teman- teman dan pacaran. Setelah itu tidak sekolah, meinginkan menikah. Hal ini dipertegaskan oleh ibu Mela alasan Mela tidak sekolah lagi mungkin garagara sering pindah rumah terpaksa dia juga pindah sekolah gara- gara pindah sekolah dia tinggal kelas, malu timbul disekolah karena postur tubuh juga besar. Setelah itu sekarang dia sering main juga tambah berteman dengan laki- laki. Tidak lama setelah itu dapat jodoh ya mau bagaimana lagi dinikahkan saja dari pada dia mainmain terus.

Wawancara dengan Nadia (17 Tahun), alasan putus sekolah karena malas pergi sekolah dan berteman dengan teman- teman tidak sekolah sehingga ikut-ikutan pacaran dan meminta menikah kepada oarang tua dan putus sekolah. Hal ini diperkuat oleh orang tua Nadia alasan anak ibu putus sekolah karena dia ingin menikah. Dia tidak mau sekolah. Susah ibu menyuruh nya sekolah tapi tetap dia tidak mau sekolah. Ini pengaruh lingkungan karena ikut-ikutan temanteman. Selama dirumah selalu diawasi kalau berteman tapi ibu kurang tau dia disekolah. Mungkin disekolah bermainmain, pacar-pacaran akhirnya tidak mau sekolah lagi. Mau bagaimana lagi kan. Kalau untuk perlengkapan dia sekolah selama ini bisa terpenuhi.

Berdasarkan wawancara diatas di Nagari Ladang Panjang penyebab anak putus sekolah di tingkat Sekolah Menengah Atas yaitu didominasi oleh faktor lingkungan sehingga anak putus sekolah memilih menikah di usia sekolah sehingga dia memutuskan untuk berhenti sekolah dengan alasan malas untuk sekolah dan kurang berminat untuk sekolah.

\section{PEMBAHASAN PENELITIAN}

Berdasarkan hasil penelitian yang diperoleh mengenai faktor penyebab anak putus sekolah di Nagari Ladang Panjang akan dibahas dalam uraian berikut ini:

\section{Faktor Internal Penyebab Anak Putus Sekolah}

\section{a. Faktor Minat Sekolah}

Minat merupakan faktor penting yang berasal dari dalam diri anak itu sendiri karena segala sesuatu yang dilakukan atas keinginan sendiri akan mendapatkan hasil yang lebih baik, jika dibandingkan dengan sesuatu yang di paksakan. Berdasarkan hasil di lapangan peneliti menemukan anak yang putus sekolah yang berdasarkan faktor minat banyak didominasi oleh anak usia tingkat Sekolah Dasar. Penyebab anak putus sekolah di Sekolah Dasar yaitu dikarenakan faktor minat dikarenakan prestasi belajar anak 
yang rendah dan kurangnya kemauan anak untuk bersekolah sehingga anak menganggap sekolah tidak menarik baginya karena tugas dan beban pelajaran disekolah yang tidak mampu diikutinya sehingga timbul rasa malas untuk sekolah dan lebih memilih bermain dirumah sehingga mengakibatkan anak tidak naik kelas dan pada akhirnya anak merasa malu dengan teman-temannya karena tinggal kelas dan akhirnya anak memutuskan untuk berhenti bersekolah. Walaupun orang tua anak sudah memberikan nasehat dan segala upaya supaya anak nya tidak berhenti sekolah. Hal ini sama yang disampaikan dengan Suyanto (2010) bahwa faktor yang menyebabkan anak putus sekolah yaitu bagi responden yang sejak awal memiliki nilai akademik yang kurang, atau kemampuan belajar yang rendah dalam arti prestasi belajarnya relatif kurang bahkan tidak naik kelas, mereka pada umumnya menyadari kelemahannya, dan menerima malah untuk tidak melanjutkan sekolah.

\section{Faktor Eksternal Penyebab Anak Putus Sekolah}

\section{a. Faktor Kondisi Ekonomi Keluarga}

Faktor ekonomi merupakan pendukung utama untuk mendukung pendidikan anak, karena dengaan ekonomi yang memadai biaya pendidikan anak akan dapat terpenuhi. Sebaliknya, apabila keadaan ekonomi orang tua kurang mampu, maka kebutuhan anak dalam bidang pendidikan tidak akan dapat terpenuhi. Seperti yang disampaikan dalam teori
Need For Achievement atau n-Ach McCleland dalam Sobur (2003), bahwa dalam sebuah masyarakat jika banyak orang memiliki $\mathrm{n}$-Ach yang tinggi, dapat di harapkan masyarakat tersebut akan menghasilkan pertumbuhan ekonomi yang tinggi. Artinya pertumbuhan ekonomi selalui didahului oleh n-Ach yang tinggi.

Hasil penelitian di Nagari Ladang Panjang, peneliti menemukan anak yang putus sekolah berdasarkan faktor kondisi ekonomi banyak terdapat anak usia tingkat Sekolah Dasar dan Sekolah Menengah Pertama faktor penyebab anak putus sekolah karena keterbatasan ekonomi orang tua, dimana orang tua tidak mampu membiayai atau mencukupi kebutuhan anak sekolah. Pendapatan orang tua yang rendah berkisar Rp 400.000-Rp 1.500 .000 perbulan dengan jumlah tanggungan 3 sampai 5 orang. Sebagian anak ini terkadang ikut mencari uang untuk memenuhi kebutuhan keluarga. Sebagian orang tua anak beranggapan pendidikan zaman sekarang merupakan beban yang paling berat dan mahal. Membuat mereka tidak mampu untuk memenuhi perlengkapan sekolah seperti seragam sekolah, biaya transportasi dan buku pelajaran dengan buku tulis yang seadanya, tas yang sederhana, dan yang memprihatinkan adalah orang tua anak biasanya bersikap acuh tak acuh pada urusan sekolah anaknya, sehingga anak sendiri kemudian tidak pernah merasakan bahwa sekolah itu memang penting bagi masa depannya sehingga anak merasa dari pada memberi beban dan akhirnya anak harus memutuskan untuk putus sekolah.

Jadi artinya bahwa banyak anak putus sekolah di nagari Ladang Panjang disebabkan karena orang tua 
termasuk anak tidak memiliki n-Ach yang tinggi sehingga dalam kehidupannya memiliki risiko kegagalan dan kesulitan sehingga tidak menjalankan tugas dengan baik. Berbanding terbalik dengan Teori Mc Cleland mengatakan jika orang punya n-Ach yang tinggi akan memiliki kebutuhan untuk berprestasi yang dianggap sangat baik. Sedangkan Jika di nagari Ladang Panjang orang tua dan anak memiliki $n$-Ach yang tinggi bearti juga akan memiliki pertumbuhan ekonomi yang tinggi sehingga tidak akan mengalami kegagalan seperti anak putus sekolah atau berhenti tengah jalan.

\section{b. Tingkat Pendidikan Orang Tua}

Tingkat pendidikan orang tua merupakan faktor penting terhadap pendidikan anak karena tinggi rendahnya pendidikan orang tua dapat mempengaruhi anak untuk melanjutkan pendidikan. sebagaimana yang disampaikan teori human capital McCleland dalam Sobur (2003) menjelaskan bahwa semakin tinggi tingkat pendikan seseorang maka semakin tinggi tingkat pendapatan nya. Semakin tinggi tingkat pendapatan maka semakin tinggi keterampilan dan pengetahuan maka semakin tinggi tingkat produktivitas. Artinya jika orang tua anak di nagari Ladang Panjang memiliki pendidikan yang tinggi maka akan menunjang pula pendidikan anaknya akan tetapi malah sebaliknya.

Berdasarkan hasil dilapangan peneliti menemukan bahwa kebanyakan anak putus sekolah di Nagari Ladang Panjang tingkat pendidikan orang tua hanyalah tamatan SD. Tingkat pendidikan orang tua yang rendah sangat terkait dengan pola pikir orang tua tentang pentingnya pendidikan bagi anak-anak mereka. Sehingga memberi pengaruh terhadap anak dalam menempuh pendidikan karena kurang sadar nya orang tua akan pentingnya pendidikan tersebut.

Sebagian orang tua anak putus sekolah di Nagari Ladang Panjang beranggapan untuk apa sekolah tinggitingi kalau akhirnya hanya bekerja serabutan, apalagi anak perempuan yang nantinya menjadi ibu rumah tangga. Sebagian orang tua anak putus sekolah di Nagari Ladang Panjang tidak menginginkan anak putus sekolah karena orang tua anak sadar akan pentingnya pendidikan di masa sekarang. Orang tua mengatakan bagaimana pun caranya untuk biaya anak sekolah akan di usahan jika benarbenar ingin sekolah. Orang tua berfikir jangan anak sama dengan orang tuanya yang hanya tamat SD kalau bisa lebih tinggi dari orang tuanya.

\section{c. Faktor Lingkungan}

Penyebab anak putus sekolah selain minat dan ekonomi keluarga yaitu penagaruh lingkungan sekitar. Hasil yang ditemukan dilapangan yaitu anak putus sekolah di Nagari Ladang Panjang kebanyakan terjadi tingkat SMP dan SMA. Dimana pengaruh lingkungan anak banyak berteman dengan teman yang tidak sekolah sehingga anak sering cabut dari sekolah dan bermain jauh di luar sekolah. Setiap hari anak merasa lebih senang 
bermain diluar dari pada masuk sekolah karena sudah keasyikan main sehingga anak malas dan akhirnya juga memutuskan untuk tidak bersekolah seperti temannya tersebut. Sebagaian anak putus sekolah di nagari ini karena adanya pergaulan bebas yang membuat anak memikir lebih baik menikah dini dari pada bersekolah. Hal tersebut yang menyebabkan anak memilih putus sekolah.

\section{PENUTUP}

\section{Kesimpulan}

Berdasarkan hasil penelitian dan pembahasan yang telah diuraikan sebelumnya, maka dapat disimpulkan faktor penyebab anak putus sekolah di Nagari Ladang Panjang Kecamatan Tigo Nagari yaitu: 1) faktor internal meliputi kurangnya minat anak untuk bersekolah dilihat dari prestasi belajar yang rendah dan kemauan belajar anak itu sendiri dengan kemampuan yang dimiliki anak rendah, dan timbul rasa malas sehingga tidak naik kelas dan malu jika melanjutkan sekolah. 2) faktor eksternal yang pertama, pendapatan oarang tua yang rendah, berkisar Rp 400.000-Rp 1.500 .000 dengan jumlah tanggungan 3 sampai 5 orang. Kemampuan ekonomi orang tua hanya cukup untuk kebutuhan seharihari dengan keterbatasan ekonomi sehingga orang tua tidak mampu mencukupi kebutuhan sekolah anak. Yang kedua lingkungan pengaruh lingkungan sekitar yaitu teman sebaya dengan sering bermain- main dengan anak yang tidak sekolah sehingga bolos sekolah dan sebagian lagi terpengaruh dengan pergaulan lawan jenis sehingga anak putus sekolah memilih menikah di usia muda dan memutuskan untuk berhenti sekolah.

\section{Saran}

Adapun saran yang dapat penulis sajikan sehubungan dengan faktor penyebab anak putus sekolah di Nagari Ladang Panjang adalah:

Diharapkan kepada orang tua agar memberikan bimbingan, perhatian dan motivasi yang penuh terhadap pendidikan anak. Orang tua harus mengontrol, mengawasi kegiatan anak sehari-hari baik segi pergaulan maupun dalam memenuhi kebutuhan anak akan pendidikan. Demi kelancaran pendidikan anak agar bisa meningkatkan minat anak untuk bersekolah.

Diharapkan kepada anak hendaknya selalu meningkatkan motivasi diri untuk bersekolah. Dapat memilah-milah mana teman yang baik dan ma yang buru supaya anak tidak terseret ke dalam hal-hal yang berdampak negatif untuk kehidupan dan masa depannya.

Diharapakan kepada masyarakat khususnya pemerintah nagari sekitar tempat tinggal anak yang bersangkutan seharusnya bisa melakukan pendataan kepada warganya yang putus sekolah di berbagai tingkatan serta mengambil tindakan untuk anak yang mengalami putus sekolah. 


\section{DAFTAR PUSTAKA}

Ajiz,Tenisa,dkk.2012. Faktor-Faktor Penyebab Anak Putus Sekolah pada Tingkat SMA di Kelurahan Gedong Meneng Kecamatan Rajabasa Kota Bandar Lampung tahun2012.Jurnal.

Bappeda Provinsi Sumatera Barat. 2016. Angka Putus Sekolah . Padang.

Peraturan Pemerintah Republik Indonesia Nomor 47 Tahun 2008.

Slameto.2003. Belajar dan faktorfaktor yang mempengaruhinya. Jakarta: Rineka Cipta.

Sobur,Alex.2003.Psikologi Umum. Bandung: Pustaka Setia.

Surtani. 2017. Upaya Meningkatkan

Aktivitas Belajar Siswa Melalui Penerapan Model Cooperative Script Pada Pembelajaran IPS di Kelas VIII.1 SMP Negeri 1 Gunung Tuleh Kabupaten Pasaman Barat. Jurnal. Hlm: 2.

Suyanto, Bagong.2010. Masalah Sosial Anak. Jakarta: Kencana Prenada Media Grup.

Undang-undang Nomor 20 Tahun 2003 tentang Sistem Pendidikan Nasional. 